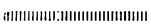

\author{
八田 夏夫*.小門 純一*.花崎 紘一* \\ 宅田 裕彦*2 . 中沢 政治*2
}

\section{Effect of Water Flow Rate on Cooling Capacity of Laminar Flow for Hot Steel Plate}

\author{
Natsuo Hatta, Jun-ichi KoKado, Koichi Hanasaki \\ Hirohiko TAKudA, and Masaharu NAKazawa
}

\begin{abstract}
Synopsis:
An experiment to examine the cooling process of a hot steel plate by the laminar water flow was carried out and the effect of the water flow rate on the cooling capacity was analytically discussed on the basis of the experimental results. The main points clarified here are as follows:

(1) The vertical distance between a nozzle exit and a cooled plate surface has almost no significant effect on the cooling capacity.

(2) The increase of the water flow rate results in the improvement of the cooling capacity. However, both the cooling capacity and the growth in black zone become saturated with the increase of the flow rate.
\end{abstract}

(3) The saturation of the cooling capacity is considered to be correlative to that of the growth in the black zone diameter.

\section{1. 緒言}

高温状態にある鋼材の水による冷却には，種々の方式 が開発され，その目的に応じて冷却の方式の選定がなさ れている.

とくに最近では，制御圧延後の加速冷却によつて，鋼 材の靱性, 強度等の機械的性質を向上させることができ るといら報告も多くなされているよらに1) 6), 压延ライ ンにおける温度制御の重要性が認識されてきている.

一方では，省資源といら立場から，できるだけ少ない 水量で効果的な鋼材の冷却を実現するための努力も必要 となつてきている。

水による強制冷却方式としては, ラミナフロ一冷却, ジェット冷却，スプレイ冷却， ミスト冷却等に分類され ている7).これらの冷却方式のらち，ラミナフロ一冷却 は，局所的ではあるが，もつとも冷却速度が高い。この ラミナフロー冷却方式は最終仕上げ压延を終了した熱延 鋼板を，ホットランテーブル上で泠却するのに採用され ている.この場合のホットランテーブル上の冷却は熱延
鋼板自体がある決められた速度で走つているので，水の り現象が牛じ，理論的な解析は林難となる。したがつて， 冷却水量および循環動力の減少を目的として，スズル配 列等の詳細な検討も，おもに実験的に行われている8

また， $400^{\circ} \mathrm{C}$ から $800^{\circ} \mathrm{C}$ の温度範用で加熱された 3 $\mathrm{mm}$ 厚の鋼板を静止させ，その上から単一層状軸対称水 流を落下させて，その冷却の挙動を実験的に調査した結 果も報告されている9)。著者らも, それに準じて冷却中 の温度と時間の関係を実測し，间時にブラックゾーンの 成長過程をパラメータとして，その実測結果と・致する ような数式モデルを見出している ${ }^{10)}$.

本研究では, $900^{\circ} \mathrm{C} に$ 加熱された久テンレス鋼板を水 のラミナフローによって冷却実験し，その鋼板の冷却能 に及ぼす水量効果について論ずることを主題としたもの である。それは冷却水量とブラックン゙ーン径の成長過程 には何らかの関係があり，それが明確にならない限り， 既報の数式モデルの使用に欠かんを生じているからであ る.また，鋼板内部の熱輸送現象が非定常であるので， 経過時間に対する鋼板内部の温度変化の様子を等温線モ

昭和 56 年 7 月 27 日受付 (Received July 27, 1981)

* 京都大学工学部 工博 (Faculty of Engineering, Kyoto University, Yoshidahonmachi Sakyo-ku Kyoto 606)

*2 京都大学工学部 (Faculty of Engineering, Kyoto University) 


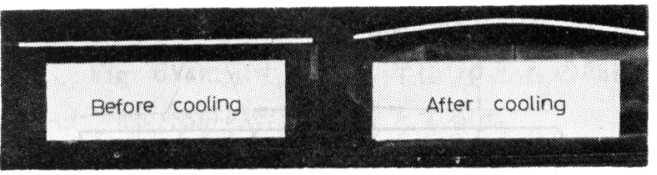

Photo. 1. Curvature of hot steel plate with $3 \mathrm{~mm}$ in thickness after laminar flow cooling.

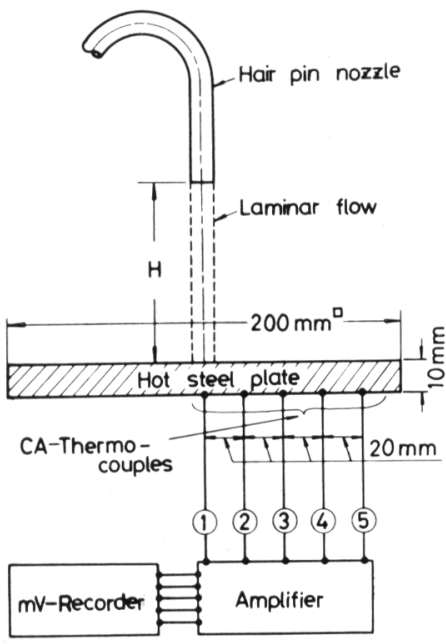

Fig. 1. Outline of the experimental apparatus and indication of temperature measuring points.

デルによつて示した.

\section{2. 実験}

\section{$2 \cdot 1$ 実験概要}

ラミナフロー冷却時の高温鋼板の温度变化の測定装置 に関しては別紙10)で詳述しているのでここでは簡単に その概要だけにとどめたい。

央験に使用した試料は厚さ $10 \mathrm{~mm}$, 一辺 $200 \mathrm{~mm}$ の 正方形の 18-8 ステンレス鋼板である. 板厚を $10 \mathrm{~mm}$ と厚くしたのは，板厚があまりらすいと，冷却中に板が そつてしまい, 衝突後の水の半径方向流れが時間的に一 様でなくなるのを防ぐためである. Photo. 1 は板厚 3 $\mathrm{mm}$ のステンレス鋼板を $900^{\circ} \mathrm{C}$ に均一に加熱し, ラミ ナフロー冷却の実験を終了したときの板のそりの状態 を，冷却前の板と対比して，示したものである.

Fig. 1 に示すように, 温度計測はラミナフローの衝突 面の裏側で行われ, 衝突点直下の中心点(1) と, 艺の点か ら半径方向に $20 \mathrm{~mm}$ の間隔で(2)〜(5)末での合計 5 点定 選んだ。それらの5点にアルメル・クロメル熱電対をと りつけ, 増幅器を介してオシログラフによつて温度推移 を記録させるようにしている。その際，各測定チャンネ ルは，相互間に外来電位差をもたないよらに，確実に分
離されている.

熱電対のついたままの鋼板を炬内温度が $900^{\circ} \mathrm{C}$ のカ 又炉に入れ，約 $90 \mathrm{~min}$ そのままに保持する。矢の後， 鋼板をガス炉から取り出し，冷却台の上にのせ，へアピ ソノズルから水を鉛直に流して，900 C に均一に加熱さ れた鋼板を冷却する。

また，本実験ではノズル出口と鋼板表面の間の鉛直距 離, すなわち Fig. 1 に示されているHは $100 \mathrm{~mm}$ から $500 \mathrm{~mm}$ の範囲, 流量 $Q$ は $1.0 \mathrm{l} / \mathrm{min}$ から $7.0 \mathrm{l} / \mathrm{min}$ の範用で行われた. これはノズル高さ $H$ と流量Qが冷却 能にどの程度の影響を与光るかを調べるためである。ま た，へアピンノズルは銅製で，その内径 $D$ は $10 \mathrm{~mm}$ で ある。

\section{$2 \cdot 2$ 実験結果}

Fig. 2 Fig. 4 は冷却水量を $3.0 \mathrm{l} / \mathrm{min}, 5.0 \mathrm{l} / \mathrm{min}$ および $7.0 \mathrm{l} / \mathrm{min}$ としたときの 測温点 (1)～(5) (Fig. 1 参照）の温度-時間の 関係の実測結果を示したものであ

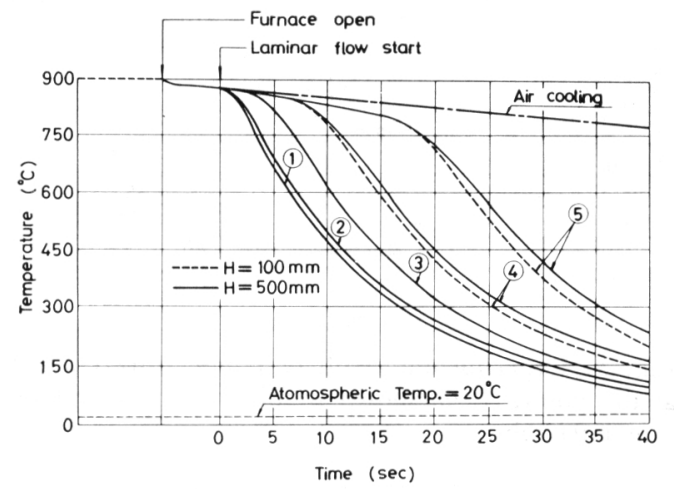

Fig. 2. Experimental result of temperature change at the points (1)-(5) shown in Fig. 1 for water flow rate $3.0 \mathrm{l} / \mathrm{min}$.

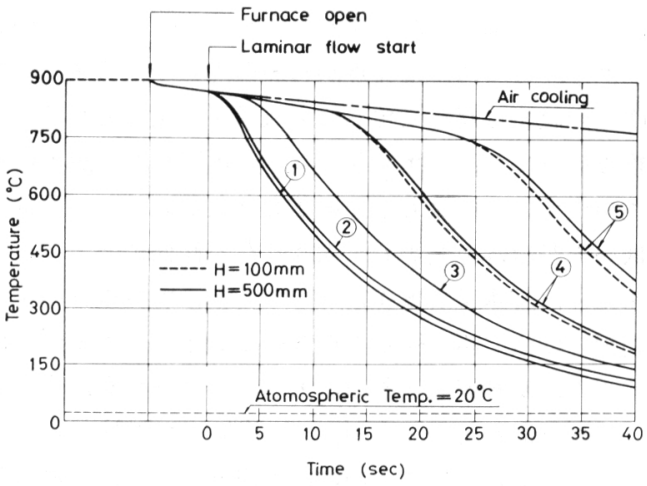

Fig. 3. Experimental result of temperature change at the points (1)-(5) shown in Fig. 1 for water flow rate $5.0 \mathrm{l} / \mathrm{min}$. 


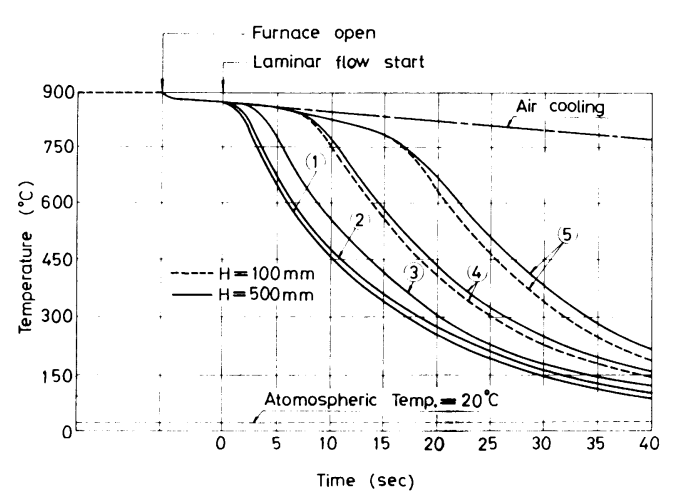

Fig. 4. Experimental result of temperature change at the points (1)-(5) shown in Fig. 1 for water flow rate $7.0 \mathrm{l} / \mathrm{min}$.

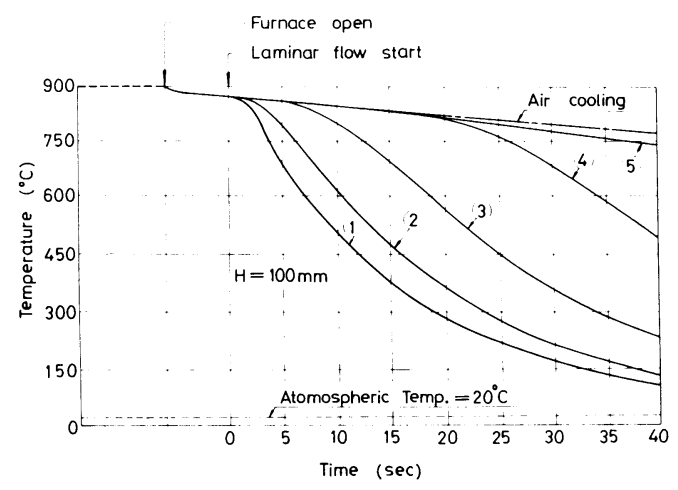

Fig. 5. Experimental result of temperature change at the points (1)-(5) shown in Fig. 1 for water flow rate $1.0 \mathrm{l} / \mathrm{min}$.

る. 実線はノズル高さ $H=500 \mathrm{~mm}$ としたときの場合で, 破線は $H=100 \mathrm{~mm}$ としたときのものである。なお， 一 点鎖線で示されているのは自然放冷の場合の先測絬果で ある、これらの実測結果から明らかなことは，ノズル高 さによつて冷却能を左右する有意な差は認められないこ とである.とくに, 衝突点から測温点(3に至るまでの温 度降下の状態はHが変化しても流量が-・定であれば, 温 度推移に束つたく変化を与劣ない, 衝突点から遠っにあ る測温点(4)之(5)では若下の影響を少えるが，ノズル高さ が低い方が冷却速度が若干大きくなる傾向にある.

また，冷却水量の多少にかかわらず，温度推移の様子 は勾配のゆるい略直線状の温度降下を示し，ある時点に 達すると, 冷却速度が急激に大きく肩状変化を示してい る.この現象がもつとも速く生ずるのは測温点(1)であ り，もつとも遅く生ずるのは測温点(5)゙ある。この肩状 のなめらかさは衝突点から離れているものほどゆるやか である.Fig. 5 は冷却水量 $Q=1.0 \mathrm{l} / \mathrm{min}$, ノズル高さ

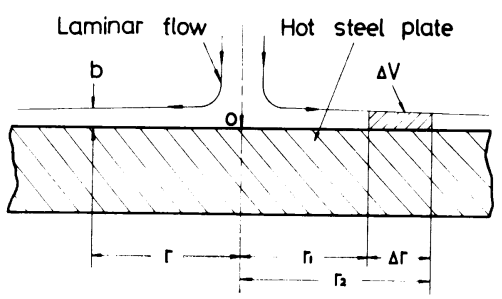

Fig. 6. Schematic view of cooling water for impinging of laminar flow with hot steel plate.

$H=100 \mathrm{~mm}$ の場命の冷却曲線であるが，ての様了を非 常によく表している。すなわも, 測温梷(5)冷却曲線に 沿つて，温度降下してきたほかの点の冷却曲線が，(1), (2)，(3)，(4)の順に分岐している。として，(1)〜 (5)の冷却 曲線の間隔は水量が少ないほどへだたり，水量が増大寸 るに伴つて，それぞれの冷却曲線は間隔を小さくしてい る.

\section{3. 検討}

ヘアピンノズルから下うへ鉛直に落トしてくるラミナ フローは，水平面上に置かれた鋼板表面に衝突し，衝突 点かららすい水膜を形成して半径方向に流れの向きを変 える、そして，衝突点を中心とする円形のブラックゾー ンが鋼板表面上に形成される。したがつて，水が鋼板表 面に衝突した後も軸対称流であると考皇られる。

一方，ブラックゾーン径は時閒の経過とともに大きく なり，冷却水はブラックゾーン外周で沸騰する.このこ とから，ブラックゾーン内では水は沸点に達していない が，水温は衝突点から半径う问に進むに從つて上昇して いると考えられる.ブラックン゙ーン径が時間の経過とと もに大きくなるのは，時々刻々と冷却毦が冷さされるに 従つて，それだけ半待の大きい俘监に米ないと水が沸点 に達しないからである。

まず，ラミナフロー冷却の冷却能を考察寸る場命に， ノズル高さHの影響の導人が必肾で方るのかどらかを検 封する.Fig. 6 はラミナフロ一の衝突点近傍の水流の 様子をモデル化したものである。いま，衝突品中心を原 点 0 とし, 半径 $r$ での水流の膜牸を $b$, 半彷方问の水流

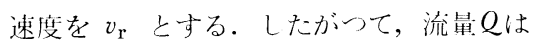

$$
Q=2 \pi r b v_{\mathrm{r}}
$$

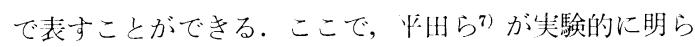
かにしているように, 衝突点近傍では半径方向の流速が 一定であると考学ると, 膜景 $b$ は半栙 $r$ のみの関数とな り，つぎの式

$$
b=B-1
$$


が得ら杖るここで， $B$ は $Q /\left(2 \pi v_{\mathrm{r}}\right)$ で定数と見なし てよい.Fig. 6 に示すように，半径 $r_{1}$ と $r_{2}$ の間にあ るドーナツ形の部分の容積を $\Delta V$ とすると,

$$
\Delta V={ }_{v_{\mathrm{r}}}^{Q}\left(r_{2}-r_{1}\right)
$$

となる. い军,この容積 $\Delta V$ の水が，高温鋼板から熱量 $\Delta q$ をらばい， $\Delta \theta_{\mathrm{w}}$ だけ水温が上昇したとすると，

$$
\Delta q=\Delta V \cdot \gamma_{\mathrm{w}} \cdot \Delta \theta_{\mathrm{w}} \cdot C_{\mathrm{w}}
$$

の関係が成り立つ, ここで， $\gamma_{\mathrm{w}}$ および $C_{\mathrm{w}}$ は水の比重 量掞よび比熱である. 铰密には, 水の膜厚方向に温度勾 配ができ, 鋼板と接触している部分の水温は高く, 大気 と接触している部分では低い。しかし，膜厚がきわめて らすいものであるとすれば，膜厚方问の温度公配は小さ く，近似的に(4)式が成り立つものとして考えてよいた 万丂.

つぎに，鋼板低而から水に移動する熱量を求める。 の祭, $r=r_{1}$ と $r=r_{2}$ の洏半径の差 $\Delta r$ をさいもの之す る.なぜなら，水流が $r=r_{1}$ から $r=r_{2}$ に達するまでの 所要時間 $\Delta t$ が小さくなるので, その閒の水温の変化が 近似的に無視できること，同時に $\Delta r$ が小さいので，そ

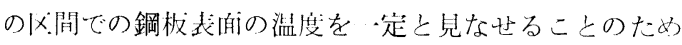
である.さて，半径 $r_{1}$ と $r_{2}$ の閒にある鋼板と水の接触 面積は $\pi\left(r_{2}^{2}-r_{1}^{2}\right)$ であるので， $\Delta t$ 時間中に鋼板表面 から水に移動する熱晕 $\Delta q$ は次式で与えられる.

$$
\Delta q=\alpha \pi\left(r_{2}^{2}-r_{1}^{2}\right)\left(\theta_{\mathrm{s}}-\theta_{\mathrm{w}}\right) \Delta t
$$

ここで， $\alpha$ は鋼梑と水との熱伝達率， $\theta_{\mathrm{s}}$ は鋼板の表而 温度, $\theta_{\mathrm{w}}$ は水湍である.

さて，鋼板が水に方えた熱量を小すす（5)式と水が受け 取つた熱暈を示す (4) 式は等しいので，半径 $r_{1}$ にあつ たときの温度から半径 $r_{2}$ の位置に来たときの温度の差 $\Delta \theta_{\mathrm{w}}$ が求めら机る。すなおり,

$$
\Delta \theta_{\mathrm{w}}=\frac{\pi \alpha\left(r_{2}+r_{1}\right)\left(\theta_{\mathrm{s}}-\theta_{\mathrm{w}}\right) v_{\mathrm{r}} \Delta t}{Q \gamma_{\mathrm{w}} C_{\mathrm{w}}}
$$

となる。

つぎに， $v_{\mathrm{r}}$ は先述したよらに一定としているので，

$$
v_{\mathrm{r}}=\frac{\Delta r}{\Delta t}=\frac{r_{2}-r_{1}}{\Delta t}
$$

となる。この関係を $(6)$ 式に適用すると，

$$
\Delta \theta_{\mathrm{w}}=\frac{\pi \alpha\left(r_{2}^{2}-r_{1}^{2}\right)\left(\theta_{\mathrm{s}}-\theta_{\mathrm{w}}\right)}{Q r_{\mathrm{w}} C_{\mathrm{w}}}
$$

が得られる。

この (8) 式には，ノズル高さHによつて支配される半 径方向速度 $v_{\mathrm{r}}$ が含まれていない.すなわち，ノズル高 さの変化が水温の上显に影響しないとしても差し支えな
いと考える.このことは，Fig. 2〜Fig. 4 に示すよう に, 温度推移の様子は冷却水量の多少によつて変化する が，ノズル出口と鋼板表面の距離 Hの大小によつてはほ とんど変化しないという実験結果と一致する.

ノズル出口での 水流速度 $V_{\mathrm{N}}$ とノズル高さ $H$ によつ て, 衝突点での流速 $V_{\mathrm{s}}$ は

$$
V_{\mathrm{S}}=V_{V_{\mathrm{N}}^{2}}^{2}+2 g H
$$

によつて計算される，したがつて，ノズル高さ $H$ をさき くすると，(9)式によつて衝突点での泠却水の流速 $V_{\mathrm{s}}$ は大きくなる．平由ら 半径 $r$ と比 $r / D$ が 5 以内であれば $v_{\mathrm{r}}=V_{\mathrm{s}}$ となるこ とを明らかにしている。したがつて，ノズル高さを大き くすることは $v_{\mathrm{r}}$ を大きくすることに寄与するが，同-.. 冷却水量の場合には，ノズル高さを低くした場合に比べ て, 衝突後の半径方向の水流の水膜がうすい. いま, $Q$ $=5 \mathrm{l} / \mathrm{min}$ の場合で, $H=500 \mathrm{~mm}$ と $H=100 \mathrm{~mm}$ とL たときの半径方向の流速 $v_{\mathrm{r}}$ と膜厚 $b$ を比較してみる. $H=500 \mathrm{~mm}$ の場命には $v_{\mathrm{r}}=3.30 \mathrm{~m} / \mathrm{s}$ であるのに対し $\tau, H=100 \mathrm{~mm}$ の場合には $v=1.76 \mathrm{~m} / \mathrm{s}$ となる. 半 径 $r$ が $5 \mathrm{~cm}$ での膜厚 $b$ は $H=500 \mathrm{~mm}$ としたときには $b=0.08 \mathrm{~mm}, H=100 \mathrm{~mm}$ のときには $b=0.15 \mathrm{~mm}$ と なる．その雨者の半径方向の流速 $v_{\mathrm{r}}$ の比は $3.30 / 1.76$ $=1.875$ で, 膜厚比は $0.08 / 0.15=1 / 1.875$ となる.

Fig. 3 に示すよらに，ノズル高さを変えても，冷却曲 線にほとんど差が認められない。このことは半径方向速 度 $v_{\mathrm{r}}$ 之膜厚 $b$ の積 $v_{\mathrm{r}} \cdot b$ によつてラミナフロー冷却能 が支配されるものと考光られる。

Fig. 7(a)，(b)，（c）は水冷開始時の温度加各 測点の温度が $600^{\circ} \mathrm{C}, 450^{\circ} \mathrm{C}$ および $300^{\circ} \mathrm{C}$ になるなで の所要時間を, 種々の流量に対して示したものである. な挴, 試料を炉から抽出して, 水冷開始までの所要時間 が約 $6 \mathrm{~s}$ であつたので, 鋼板の表面温度はその間に約 40 ${ }^{\circ} \mathrm{C}$ 降トしている.これらの図によると, 衝突点直下（測 点(1)）温度降トの状態は流量の多少にかかわらず不変 であることがわかる。これはラミナフローの衝突点から 半径方向に層状の流れが生じ, 衝突点から遠くなればな るほどサブクール温度差が小さくなる，それに対して， 衝突点では供給される新鮮な冷却水の温度は常に等し く, サブクール温度差に変化がないからであると考觉ら れる。

また, 冷却水量が増すに従つて, ある一定の温度に達 するまでの冷却時間は短縮されるが， ある限界值以上に なると, 冷却能を促進する効果は弱められている. 本実 験の場合では, 冷却水量を $4 \sim 5 \mathrm{l} / \mathrm{min}$ 以上にして子冷 却速度を大きくする効果はほとんど垫められない。 

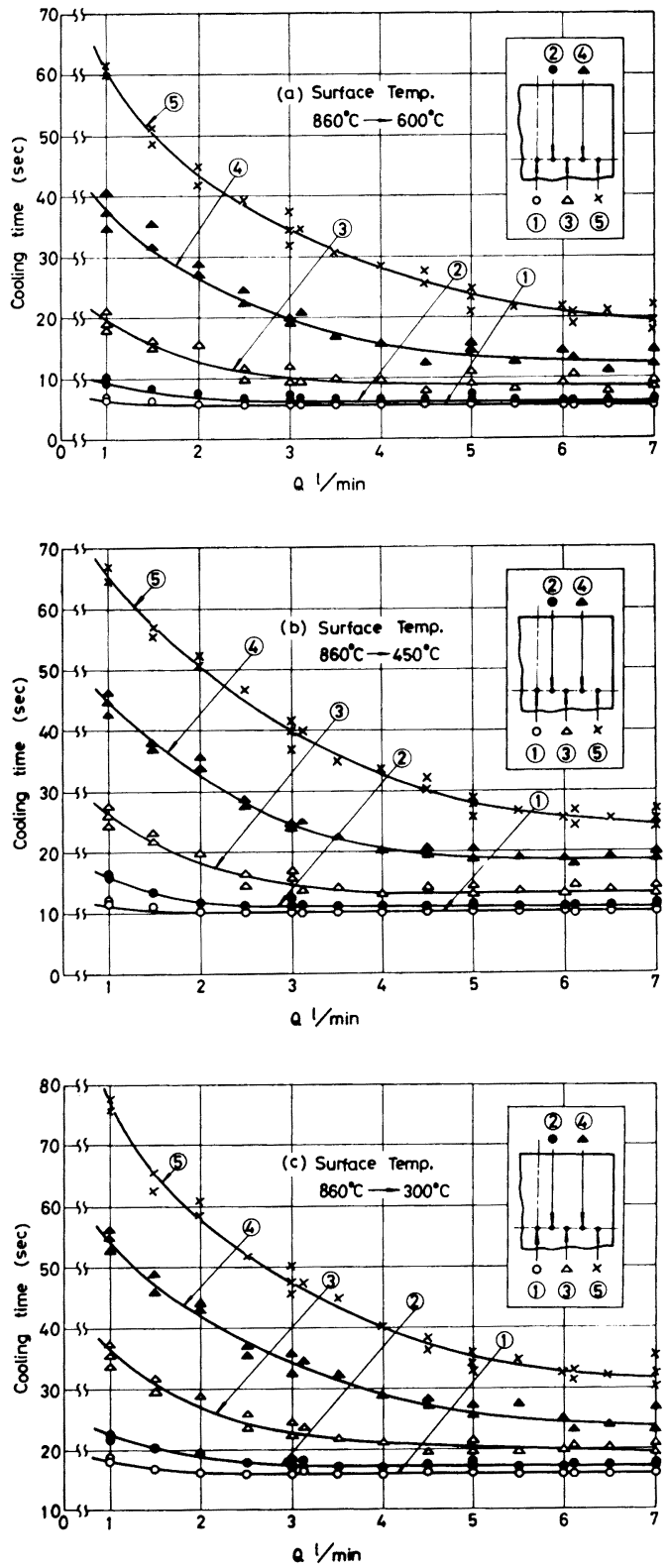

Fig. 7. Relation between water flow rate and the cooling time, during which the temperature in the measuring points (1)-(5) shown in Fig. 1 falls to 600 ${ }^{\circ} \mathrm{C}$ (a), $450^{\circ} \mathrm{C}$ (b) and $300^{\circ} \mathrm{C}$ (c).

Fig. 8 は水冷開始後の経過時間 $\mathrm{t}$ とブラックゾーン 半径 $R_{\mathrm{B}}$ の関係を写真撮影によつて测定した絬果を焦級 したものである.これによつてもおかるよらに，冷却水 量の増大とともに，ブラックゾーン半径はより速く大き くなるが，大友ら ${ }^{9}$ も指摘しているように，限界がある.

Fig. 7(a)，(b)，(c) に示したように，ある程度の

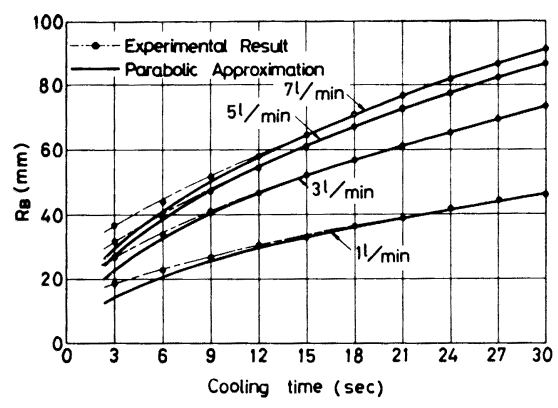

Fig. 8. Relation between the black zone radius and cooling time as parameter of flow rate.

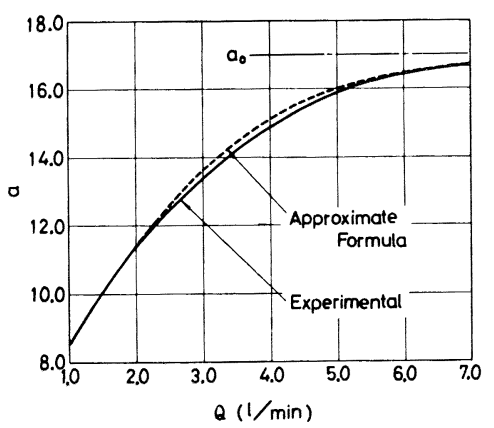

Fig. 9. Relation between flow rate and constant "a" determinating growth of black zone radius.

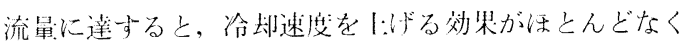
なり，Fig. 8 にホすよよりに,ゾラックゾーン栙の大きさ にも限界を生じている。すなおけ, ブシックン゙ーン径の 成長速度の遅速は, ラミナフロ一冷却の冷却能の伻価を 決定する大きな型糸のい一であると考えることができ る.

さて, 著者らは別献10によつてゾョックゾーン半径 $R_{\mathrm{B}}$ が

$$
R_{\mathrm{B}}-a \vee t
$$

によつて近似できることをぶした。ここで，aは比例定 数であるが，流莗によつて琵なる。 Fig. 8 にふされて いる夹線は測定結果を(10) 式に小されている形に放物近 似したときのブラックゾーン将と冷却時间の阙係を成 に示したものである。 その際, 檑々の流早に対して, 比 例定数 $a$ が得られる.

Fig. 9 は流晕Qと比例定数 $a$ の関係を小すものであ る。これかられかるよらに，流早が増加するに従つて， aの值も大きくなるが，Q=4〜 $5 \mathrm{l} / \mathrm{min}$ 以に:になると， ての増加率はさほど显著でなくなる。

いま, Fig. 9 において, Qの增分に対する $a$ の増分. すなわち $d a / d Q$ の様子を調べてみる. 流量Qが $1 \sim 2$ $l / \min$ 程度の少ない場命には, $Q$ の增加に伴つて, $a$ 
の増加は略值線的である.しかし, 流量が充分大きいと

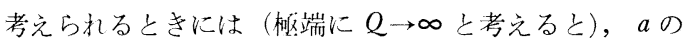
増加はほとんどなく， $a_{\mathbf{0}}(=$ 定值）に飽和している. きわめて概念的ではあるが，このよらな現象をつぎの よらなもつとも簡単と思われるロギスティック方程式 (Logistic equation) 11) を利用して, 検討してみたい。こ の方程式はある物荲（生物でもよい）の増加率が, 初期 の状態から，時間経過とともに飽和してしまら現象を子 測するのに用いられるものである。したがつて，Qの増 加にしたがつて， $a$ がある・定值 $a_{0}$ に飽和する現象と 類似していると考えられる。そのとき， ロギスティク力 程式は簡単な微分お程式で表され，

$$
\frac{d a}{d Q}=c a\left(a_{0}-a\right)
$$

と書ける。ここで，cは定数である.この式で相対的に 小さい流量 $Q$ が $Q_{1}$ のとき， $a=a_{1}$ であるとすると，

$$
\left.\frac{d a}{d Q}\right|_{\mathbf{Q}=Q_{1}}=c a_{1}\left(a_{0}-a_{1}\right)=\text { 一定 }(\neq 0)
$$

となる、つぎに，Qが相対的に十分大きいとき， $a \rightarrow a_{\mathbf{0}}$ となるので,

$$
d a \rightarrow 0
$$

となる。したがりて，(11) 式は $Q$ とaの関係を大まか に表現しているものと考える.（11)式の解は容易に得ら れ,

$$
Q={ }_{c a_{0}}^{1} \ln \frac{a}{a_{0}-a}+A .
$$

となる.ここで， $A$ は積分定数であるので， $Q=Q_{1}$ の とき $a=a_{1}$ であるとすると, (14) 式は次式のように書 ける.

$$
Q-Q_{1}-\frac{1}{\alpha} \ln \begin{gathered}
K a \\
a_{0}-a_{1}
\end{gathered}
$$

ここで, $K=\left(a_{0}-a_{1}\right) / a_{1}, \alpha=c a_{0}$ で定数である.これか ら $a$ を陽に表示すると,

$$
a=a_{0} \frac{\exp \left\{\alpha\left(Q-Q_{1}\right)\right\}}{K+\exp \left\{\alpha\left(Q-Q_{1}\right)\right\}}
$$

となる。

いま, Fig. 9 から $a_{0}=17.0$ とする. なた, $Q=1.0$ $l / \mathrm{min}$ のとき, $a_{1}=8.5$ となるので $K=1$ となる.

Fig. 9 の破線で表示され九た曲線は $\alpha=0.7$ (この値は $Q$ $=1.5 \mathrm{l} / \mathrm{min}$ のとき， $a=10$ になるよらに決定）とした ときのQとaの関係である。これからわかるよらに，流 量の多い飽和域にあるときの $a$ と, 流量の少ない増加域 にあるときの $a$ とから，澗域の $Q$ と $a$ の関係を見積も
つたことになつているので，幾分誤差はあるが，少なく ともこの場合の䛊差は無視できる程度と考える、だから といつて，(16)式によつて表現されたQと $a$ の関係式の 妥当性を論証したことにはならないが，一つの目安には なると考える.

したがつて, (10) 式に亦されるブラックゾーン半径 $R_{\mathrm{B}}$ の一般的な表現形式は近似的に,

$$
R_{\mathrm{B}}=a_{\mathbf{0}} \frac{\exp \left\{\alpha\left(Q-Q_{1}\right)\right\}}{K+\exp \left\{\alpha\left(Q-Q_{1}\right)\right\}} \vee \bar{t}
$$

で与えられてもいいと思5。

著者らが行つた堾験は，先述したように，冷却水量 $Q$ が $1.0 \mathrm{l} / \mathrm{min}$ 以上について行つたもので, その場合の $R_{\mathrm{B}}$ は

$$
R_{\mathrm{B}}=17 \frac{\exp \{0.7(Q-1)\}}{1+\exp \{0.7(Q-1)\}} \vee \bar{t}
$$

\section{として差し支えない。}

また， 8 )式において，流量Qを無限大にすると，水 温の上昇がなくなるので，水の沸騰半径で示されるブラ ックン゙ーン領域は無限域になる。このことは現象と矛盾 ナる、その意味において，(17)式あるいは(18)式は冷却 水量をいくら増加しても, 冷却領域はさ注ど拡大されな いことを亦すためのものである。

\section{4. 鋼板内部の温度推移の計算結果}

ここでは, $900^{\circ} \mathrm{C}$ に均・に加熱された $10 \mathrm{~mm}$ 厚の大 テンレス鋼板を，その上面に冷却媒体である単一層状軸 対称水流を落卜させることによつて冷却し，その冷却過 程を鋼板の疃面で温度一時間の関係を用いて実測してい る.その祭，鋼板裏面の温度-時間の実測結果と一致す るよらな数式モデルを見出し，その詳細については別 紙10)で述べている。すなわち，

1) ラミナフローによる強制冷却領域は円形で，その 半径 $R_{\mathrm{w}}(\mathrm{mm})$ は,

$$
R_{\mathrm{w}}=a V t+b(b: \text { 定数 })
$$

で与えられると考えた。ここで， $a V t$ は水冷開始後の 時刻 $t$ におけるブラックゾーン半径 $R_{\mathrm{B}}$ である.

2) 半径 $R_{\mathrm{w}}$ の強制冷却領域での冷却水と鋼板表面と の熱伝達率 $\alpha\left(\mathrm{kcal} / \mathrm{m}^{2} \mathrm{~h}^{\circ} \mathrm{C}\right)$ は鋼板表面温度 $\theta_{\mathrm{s}}$ と水温 $\theta_{\mathrm{w}}$ の差の関数とし,

$$
\alpha=500\left(\theta_{\mathrm{s}}-\theta_{\mathrm{w}}\right)^{1 / 2}
$$

でケえられると考えた。なお，この数式モデルの詳紼は 文献 $(10)$ を参照願いたい。

さて, (19) 式に示される強制冷却半径 $R_{\mathrm{w}}$ を支配する 比例定数 $a$ は, すでに述べたように, 冷却水量Qによつ 

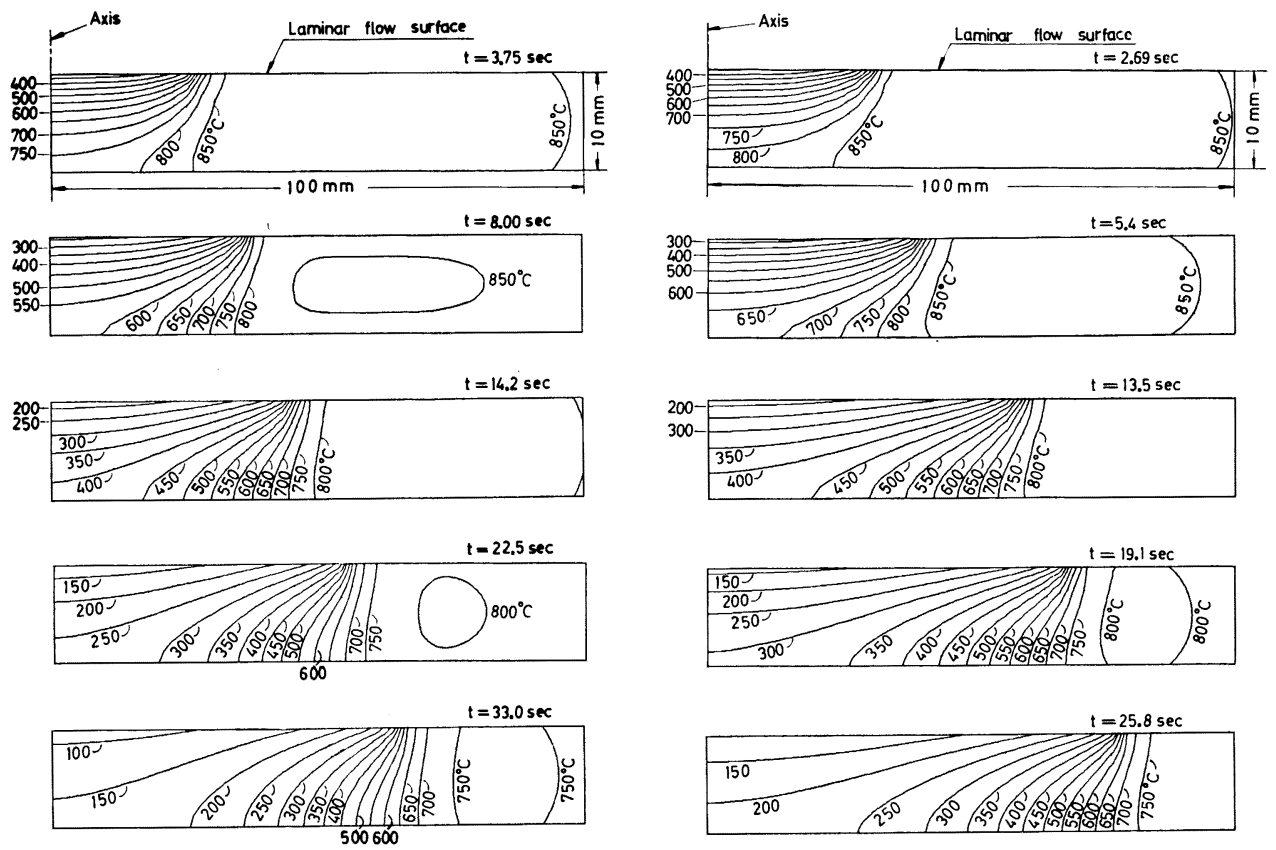

(a) $Q=1.01 / \mathrm{min}$

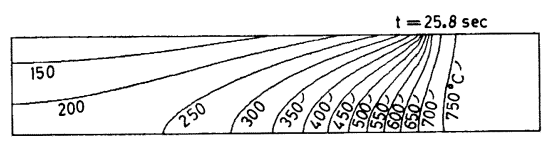

(b) $Q=3.0 \% \mathrm{~min}$
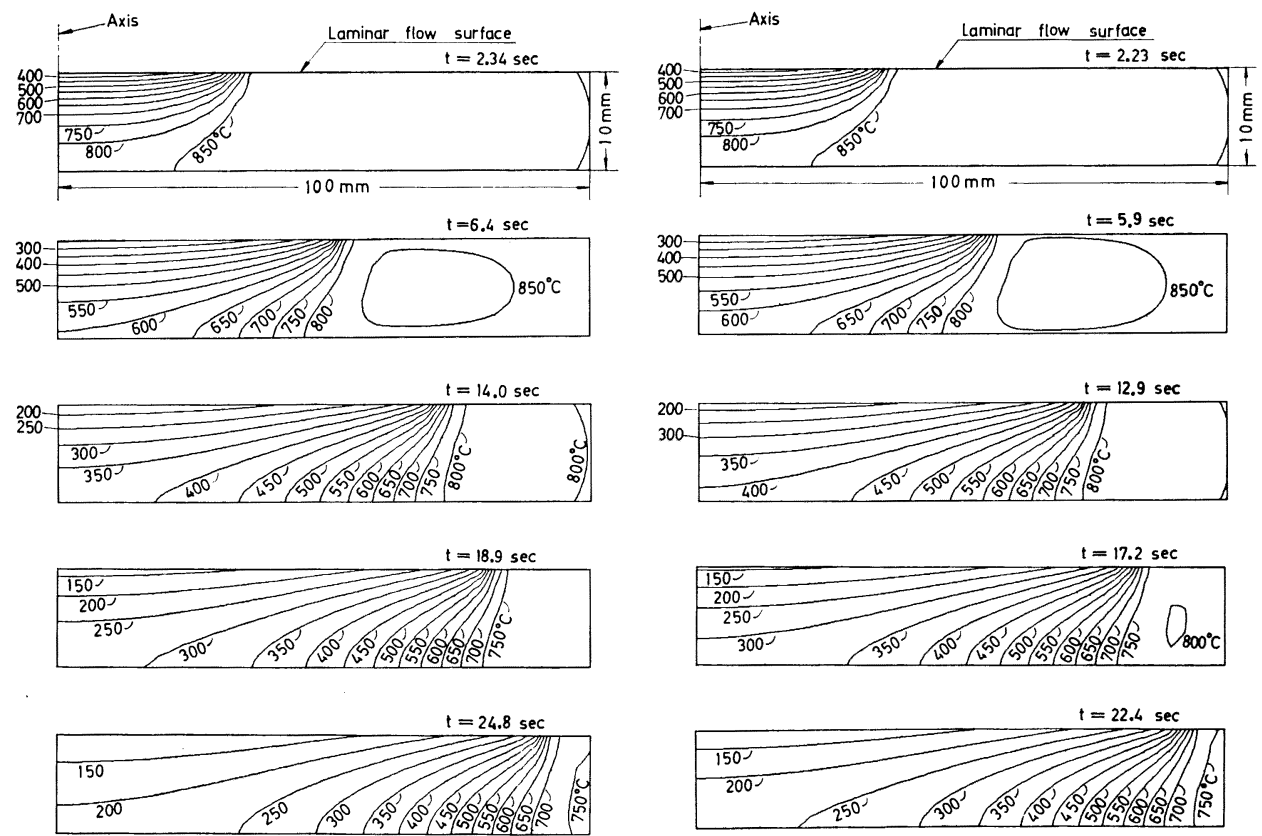

(c) $Q=5.01 / \mathrm{min}$

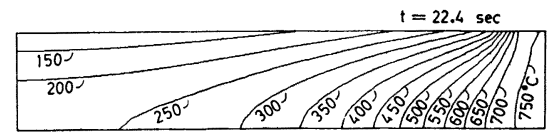

(d) $Q=7.01 / \mathrm{min}$

Fig. 10. Change of tempertuare distribution indicated by isothermal lines with elapsed time. 
て異なつた做を持つ。 Fig. 9 にボすよらに，Q=1.0 $l / \mathrm{min}$ のとき $a=8.5, Q=3.0 \mathrm{l} / \mathrm{min}$ のとき $a=13.3$, $Q=5.0 \mathrm{l} / \mathrm{min}$ のとき 15.8 および $Q=7.0 \mathrm{l} / \mathrm{min} の と$ き $a=16.8$ とし，いず机のQに対しても，(19)式にお ける $b$ を 10.0 として，鋼板内部の温度が時閏的にどの ように変化与るかを胡算してみた。

Fig. 10(a)，（b)，（c)，（d）は冷却水㫣が次ぞ れ $1.0 \mathrm{l} / \mathrm{min}, 3.0 \mathrm{l} / \mathrm{min}, 5.0 \mathrm{l} / \mathrm{min}$ および $7.0 \mathrm{l} / \mathrm{min}$ の場命の温度状態を等位線 (等温線) ブログラムを用い て，鋼板の半断面にプリンター・プロッターで描かせた ものである。等温線は温度差 $50^{\circ} \mathrm{C}$ ごとに描かれてい る。亦た，䦷けに汒された $t$ は水冷開始直後からの時刻 である. Fig. 2〜Fig. 5 に心さされているラミナフロー

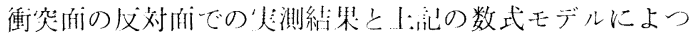

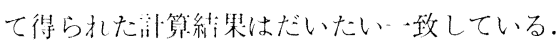

さて, 以部の盕度变化の様子については, 水冷開始初 期にはラミナフローの衝突点近傍で板厚力问に著しい温 度勾配が生じている。しかし，時間経過とともに板厚方 向の温度创配は緩和される反而，半径方向の温度公配が 顕著となる。

また，当然のことであるが，冷却水革が多い場命には 半径う问の彾却領域が大きく，少ない場合には冷却領域 は小さい，例㫕ば， $Q=7.0 \mathrm{l} / \mathrm{min}$ の場合で $t=12.9 \mathrm{~s}$ のとさと, $Q=1.0 \mathrm{l} / \mathrm{min}$ の場命で $t=14.2 \mathrm{~s}$ とを比較

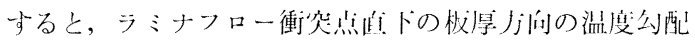
はだたた㞹じであるが，放者のうが冷却領域の半径は 1.6 倍程度大きい. したがつて, 水星此が 7 倍に対し て，冷却面積此が 2.6 倍程度といらことになる。

つぎに，冷却開始後の侍間経過に伴ら鋼板の上面とト 面の温度差は冷却水胆が多いものほど著しい。

なおこれらの戍の中で等温線が閉曲線になつている のは，強制冷却による熱伝導と側壁からの熱ふく射によ る熱伝導によつて形成されたものであると考光る。した がつて, 閉曲線从部の賉度は閉曲等温線上に記された滥 度より尚い。

\section{5. 結}

\section{論}

本研究は単 一普状軸対称水流によつて高温鋼板の冷却 央験を行い，その結果に基づいて，ラミナフロー冷却能 に関与すると考它られる因子，古なわちノズル高さ効果 および水早效果について検缡を加えたものである。これ らの検刦によつて明らかとなつた事項を要約すると以ト のようである。

1) 流量が一定でも，ノズル高さを変えると，ラミナ フローが鋼杖に衝突して以後の半往力j问速度 $v_{\mathrm{r}}$ が变化 ずるが， $v_{\mathrm{r}}$ の大小によつてラミナフロー冷却能に及ぼ

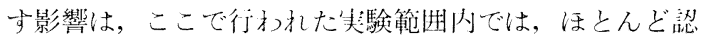
めら机なかつた。

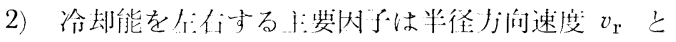
膜厚. $b$ の積 $v_{\mathrm{r}} \cdot b$ ，すなお冷却水星Q $Q$ である.ただし， Qがある程度以上になると冷却能は飽和状態に澾する。 ここで行われた瑪では $Q \fallingdotseq 5 \mathrm{l} / \mathrm{min}$ で泠却限界があ るよらである。

3) その冷却限界はブラックゾーン半径 $R_{\mathrm{B}}$ の成長限 界によつて知ることができる。

4) 経過時间 $t(\mathrm{~s})$ に打忛る $R_{\mathrm{B}}(\mathrm{mm})$ は近似的に

$$
R_{\mathrm{B}}-a_{0} \frac{\exp \left\{\alpha\left(Q-Q_{1}\right)\right\}}{K+\exp \left\{\alpha\left(Q-Q_{1}\right)\right\}} V t
$$

で衣すことができよう。ここで $a_{0}, K$ および $\alpha$ は定数 でありここで行われた験籁明では $a_{0}=17.0, K=$ $1.0, \alpha=0.7$ となつた.

5）既報10)によつて示された冷却の数式モデルによつ て内部の淔度変化の様子を胡算して及ると，水冷開始初 期にはラミナフローの衝突点近修で板厚打们に著しい温

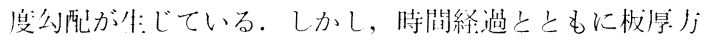

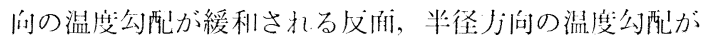
顕著となる。

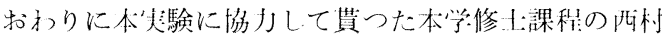

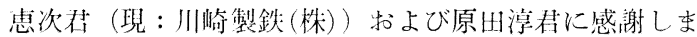
5.

\section{文献}

1)大内千秋，大北智主，山本足弘：鉄と銓， 67 (1981) 7, p. 129

2) 大北智良，大内千秋，小指軍头：鉄と銓， 63 (1977) 11，\$ 798

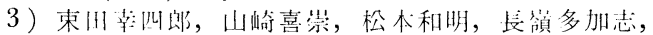

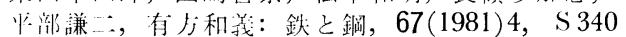

4) 山本分弘，大内千秋，大北智良：鉄と鋼， 67 (1981) 4, S 635

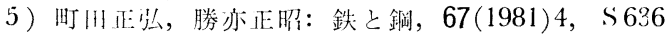

6 ）志賀千兒，天野虔一，波开村根生，鎌田晃郎：鉄 之镃，67 (1981) 4, \$ 637

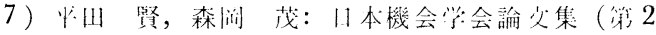
激)，42 (1976) 353, p. 236

8 ) 杉山峻一，野口孝努，神尾莫，国阔計夫：口本 鋼管技報，88 (1981)，p. 39

9 ) 大友朗紀，山口喜弘，水田篤势，大仯莫，柚埇 英則：鉄と鋼，64（1978） 11，S 707

10）八明夏夫，小門純一，花崎紘一：鉄之銓， 67 (1981) 7, p. 959

11) J. M. Sмгтн : Mathematical Ideas in Biology, Cambridge at the Univ. Press, (1968), p. 40 